\title{
Triple-negative breast cancer: recent treatment advances
}

\section{[version 1; peer review: 2 approved]}

\author{
Alice R T Bergin (Di)1, Sherene Loi (D)1,2 \\ ${ }^{1}$ Peter MacCallum Cancer Centre, Melbourne, Victoria, Australia \\ ${ }^{2}$ Sir Peter MacCallum Department of Oncology, University of Melbourne, Melbourne, Victoria, Australia
}

V1 First published: 02 Aug 2019, 8(F1000 Faculty Rev):1342

https://doi.org/10.12688/f1000research.18888.1

Latest published: 02 Aug 2019, 8(F1000 Faculty Rev):1342

https://doi.org/10.12688/f1000research.18888.1

\section{Abstract}

Triple-negative breast cancer (TNBC) is a breast cancer subtype renowned for its capacity to affect younger women, metastasise early despite optimal adjuvant treatment and carry a poor prognosis. Neoadjuvant therapy has focused on combinations of systemic agents to optimise pathological complete response. Treatment algorithms now guide the management of patients with or without residual disease, but metastatic TNBC continues to harbour a poor prognosis. Innovative, multi-drug combination systemic therapies in the neoadjuvant and adjuvant settings have led to significant improvements in outcomes, particularly over the past decade. Recently published advances in the treatment of metastatic TNBC have shown impressive results with poly (ADP-ribose) polymerase (PARP) inhibitors and immunotherapy agents. Immunotherapy agents in combination with traditional systemic chemotherapy have been shown to alter the natural history of this devastating condition, particularly in patients whose tumours are positive for programmed cell death ligand 1 (PD-L1).

Keywords

Triple negative breast cancer, Immunotherapy

\section{Open Peer Review}

Approval Status

1 2

version 1

02 Aug 2019

Faculty Reviews are review articles written by the prestigious Members of Faculty Opinions. The articles are commissioned and peer reviewed before publication to ensure that the final, published version is comprehensive and accessible. The reviewers who approved the final version are listed with their names and affiliations.

\section{Kazuaki Takabe ID, Roswell Park Cancer} Institute, Buffalo, USA

The State University of New York Buffalo, Buffalo, USA

2. Heather L. McArthur, Cedars-Sinai Medical Center, Los Angeles, USA

Any comments on the article can be found at the end of the article. 
Corresponding author: Sherene Loi (sherene.loi@petermac.org)

Author roles: Bergin ART: Investigation, Methodology, Writing - Original Draft Preparation; Loi S: Supervision, Validation, Writing Review \& Editing

Competing interests: $A B$ has received travel funding from Pfizer. SL receives research funding to her institution from Novartis, BristolMyers Squibb, Merck, Roche-Genentech, Puma Biotechnology and Pfizer. She has acted as consultant (not compensated) to Seattle Genetics, Pfizer, Novartis, Bristol-Myers Squibb, Merck and Roche-Genentech.

Grant information: The author(s) declared that no grants were involved in supporting this work.

Copyright: @ 2019 Bergin ART and Loi S. This is an open access article distributed under the terms of the Creative Commons Attribution License, which permits unrestricted use, distribution, and reproduction in any medium, provided the original work is properly cited.

How to cite this article: Bergin ART and Loi S. Triple-negative breast cancer: recent treatment advances [version 1; peer review: 2 approved] F1000Research 2019, 8(F1000 Faculty Rev):1342 https://doi.org/10.12688/f1000research.18888.1

First published: 02 Aug 2019, 8(F1000 Faculty Rev):1342 https://doi.org/10.12688/f1000research.18888.1 


\section{Introduction}

Triple-negative breast cancer (TNBC) is a molecularly diverse ${ }^{1}$ breast cancer subtype currently defined by what it lacks. With hormone receptor immunohistochemistry (IHC) stains of less than $1 \%$ for oestrogen and progesterone ${ }^{2}$ and the absence of HER2 protein overexpression or HER2 gene amplification (or both $)^{3}$, TNBC accounts for 12 to $17 \%$ of all breast cancers, typically affects younger women and typically carries a poor prognosis. Metastatic progression in this phenotype is typically marked by early relapse and a predominance of hepatic, pulmonary and central nervous system metastasis ${ }^{5}$.

Despite, or perhaps because of, its aggressive nature and the lack of current targeted treatments, significant clinical and laboratory research is providing nuanced treatment options. Historically, chemotherapy has been the only viable systemic treatment option for early and advanced disease. However, recently published clinical trials have shown that immunotherapy has an important role in the treatment paradigm of this devastating condition.

\section{Neoadjuvant chemotherapy for early-stage disease and optimising rates of pathological complete response}

Although it is generally accepted that early-stage TNBC is chemotherapy-sensitive, the optimal treatment regimen remains undefined. Neoadjuvant chemotherapy is a standard of care for a locally advanced or inoperable TNBC. A major advantage of this approach is the ability to pre-emptively predict survival according to the presence or absence of a pathological complete response (pCR) at the time of surgery and tailor adjuvant therapy. Patients with TNBC, as opposed to those with the luminal subtypes, are more likely to achieve a pCR with neoadjuvant chemotherapy ${ }^{6}$. Achieving pCR (defined as no invasive or in situ disease in the breast or lymph nodes) at the time of surgery is associated with a significant improvement in disease-free survival $(\mathrm{DFS})^{7-9}$; as such, $\mathrm{pCR}$ is considered a surrogate outcome end point. However, it is unclear whether changes in pCR will ultimately equate to improvements in overall survival (OS) and thus the use of $\mathrm{pCR}$ as a robust trial end point is debated.

Clinicians often adopt an intensive approach with sequential anthracycline and taxane regimens and the evidence for this derives from retrospective, subgroup analyses of clinical trials reported before 2010 (Table 1)

Anthracyclines alone had reported pCR rates of 14 to $47 \%^{10,11}$, whereas sequential anthracycline and taxane regimens had reported pCR rates of 17 to $39 \% \%^{6,12-17}$. GeparTrio reported pCR rates up to $57 \%$ for TNBC managed with neoadjuvant anthracyclines, cyclophosphamide and taxanes ${ }^{18}$. Since then, clinical trials have attempted to define which combination of systemic agents results in the highest rates of pCR (Table 2).

Table 1. Neoadjuvant breast cancer clinical trials pre-2010, including patients with triplenegative breast cancer and showing modest pathological complete response rates with combinations of chemotherapy.

\begin{tabular}{|c|c|c|c|}
\hline $\begin{array}{l}\text { Number of patients with } \\
\text { triple-negative breast cancer }\end{array}$ & $\begin{array}{l}\text { Trial arms } \\
\text { (number of patients) }\end{array}$ & $\begin{array}{l}\text { Pathological complete } \\
\text { response rate }\end{array}$ & Reference \\
\hline 96 & $\begin{array}{l}\text { Intensified FAC (56) } \\
\text { FEC (40) }\end{array}$ & $\begin{array}{l}\text { Intensified FAC: } 47 \% \\
\text { FEC: } 13 \% \text { Combined: } \\
29 \%\end{array}$ & 10 \\
\hline 120 & FAC or FEC & $17 \%$ & 11 \\
\hline 22 & T-FAC & $45 \%$ & 19 \\
\hline 23 & Anthracycline and taxane & $39 \%$ & 12 \\
\hline 34 & $\mathrm{AC} \pm$ taxane & $27 \%$ & 13 \\
\hline 47 & $D$ and $A$ & $17 \%$ & 14 \\
\hline 255 & $\begin{array}{l}\text { A: FAC or FEC or AC (70) } \\
\text { B: T-FAC or T-FEC (125) } \\
\text { C: Taxane only (17) } \\
\text { D: Other (43) }\end{array}$ & $\begin{array}{l}\text { A: } 20 \% \text { B: } 28 \% \text { C: } 12 \% \\
\text { D: } 14 \%\end{array}$ & 6 \\
\hline 45 & $\mathrm{AC} \rightarrow \mathrm{T}$ & $34 \%$ & 15 \\
\hline 21 & Anthracycline and taxane & $38 \%$ & 16 \\
\hline 38 & AC or AT Or T/cape & $34 \%$ & 17 \\
\hline 22 & Cis & $23 \%$ & 20 \\
\hline 12 & $\mathrm{Cp}$ and $\mathrm{T}$ & $67 \%$ & 21 \\
\hline 30 & $\mathrm{E} / \mathrm{Cis} / \mathrm{F} \rightarrow \mathrm{T}$ & $40 \%$ & 22 \\
\hline 125 & Platinum and $D \pm A C$ & $34 \%$ & 23 \\
\hline 10 & Cis & $90 \%$ & 24 \\
\hline
\end{tabular}

A, doxorubicin; AC, doxorubicin and cyclophosphamide; Cape, capecitabine; Cis, cisplatin; Cp, carboplatin; D, docetaxel; E/Cis/F, epirubicin and cisplatin and 5-fluorouracil; FAC, 5-fluorouracil and doxorubicin and cyclophosphamide; FEC, 5-fluorouracil and epirubicin and cyclophosphamide; T, paclitaxel. 


\begin{tabular}{|c|c|c|c|}
\hline $\begin{array}{l}\text { Study } \\
\text { Phase } \\
\text { ClinicalTrials.gov Identifier }\end{array}$ & $\begin{array}{l}\text { Number of } \\
\text { patients }\end{array}$ & Trial arms & $\begin{array}{l}\text { Pathological complete } \\
\text { response }\end{array}$ \\
\hline \multicolumn{4}{|l|}{ PARP inhibitors } \\
\hline $\begin{array}{l}\text { BrighTNess }^{25} \\
\text { Phase } 3 \\
\text { NCT02032277 }\end{array}$ & $\begin{array}{l}\text { A: } 316 \text { B: } 160 \\
\text { C: } 158\end{array}$ & $\begin{array}{l}\text { A: Veliparib }+\mathrm{Cp}+\mathrm{T} \rightarrow \mathrm{AC} \\
\text { B: Placebo and } \mathrm{Cp} \text { and } \mathrm{T} \rightarrow \mathrm{AC} \\
\mathrm{C}: \text { Placebo and } \mathrm{T} \rightarrow \mathrm{AC} .\end{array}$ & A: $53 \%$ B: $58 \%$ C: $31 \%$ \\
\hline $\begin{array}{l}\text { Talazoparib }^{26} \\
\text { Phase } 2 \\
\text { NCT02282345 }\end{array}$ & 17 & $\begin{array}{l}24 \text { weeks Tala } \\
\text { (no neoadjuvant chemotherapy) }\end{array}$ & $47 \%^{\mathrm{a}}$ \\
\hline \multicolumn{4}{|c|}{ Anthracycline, taxane and platinum combinations } \\
\hline $\begin{array}{l}\text { GeparSepto GBG } 69^{27} \\
\text { Phase } 3 \\
\text { NCT01583426 }\end{array}$ & 276 & $\mathrm{Nab}-\mathrm{pac} \rightarrow \mathrm{EC} \mathrm{Pac} \rightarrow \mathrm{EC}$ & Nab-pac: $56 \%$ Pac: $37 \%$ \\
\hline $\begin{array}{l}\text { ETNA }^{28} \\
\text { Phase } 3 \\
\text { NCT01822314 }\end{array}$ & 219 & $\begin{array}{l}\mathrm{Nab}-\mathrm{pac} \rightarrow \mathrm{AC} \text { or } \mathrm{EC} \text { or } \mathrm{FEC} \mathrm{Pac} \rightarrow \mathrm{AC} \\
\text { or } \mathrm{EC} \text { or } \mathrm{FEC}\end{array}$ & Nab-pac: $41 \%$ Pac: $37 \%$ \\
\hline $\begin{array}{l}\text { WSG-ADAPT-TN } 29 \\
\text { Phase } 2 \\
\text { NCT01815242 }\end{array}$ & 336 & Nab-pac and gem Nab-pac and Cp & $\begin{array}{l}\text { Nab-pac and gem: } 28.7 \% \\
\text { Nab-pac and Cp: } 45.9 \%\end{array}$ \\
\hline $\begin{array}{l}\text { Phase } 2^{30} \\
\text { NCT01276769 }\end{array}$ & 91 & $\begin{array}{l}\mathrm{T} \text { and } \mathrm{Cp} \rightarrow \text { surgery } \rightarrow \text { anthracycline } \\
\mathrm{EP} \rightarrow \text { surgery } \rightarrow \text { taxane }\end{array}$ & T and Cp: $38.6 \%$ EP: $4 \%$ \\
\hline $\begin{array}{l}\text { GEICAM/2006-03 }{ }^{31} \\
\text { NCT00432172 }\end{array}$ & 94 & EC-D or EC-D and Cp & EC-D: 30\% EC-D \& Cp: 30\% \\
\hline $\begin{array}{l}\text { Cisplatin-1 } \\
\text { NCT00148694 }\end{array}$ & 28 & $\begin{array}{l}\text { Neoadjuvant cis } \rightarrow \text { surgery } \rightarrow \text { adjuvant } \\
\text { chemotherapy }\end{array}$ & $22 \%$ \\
\hline $\begin{array}{l}\text { Phase } 1^{33} \\
\text { NCT01090128 }\end{array}$ & $\begin{array}{l}10 \\
\text { (TNBC cohort) }\end{array}$ & Nab-pac AC & $100 \%$ \\
\hline \multicolumn{4}{|c|}{ Chemotherapy backbone with or without novel agents } \\
\hline $\begin{array}{l}\text { PrECOG } 0105^{34} \\
\text { Phase } 2 \\
\text { NCT00813956 }\end{array}$ & 80 & Gemcitabine, $\mathrm{Cp}$, iniparib & $36 \%$ \\
\hline Cisplatin-2 NCT00580333 & 51 & Cis and Bev & $16 \%$ \\
\hline $\begin{array}{l}\text { CALGB } 40603^{35} \\
\text { Phase } 2 \\
\text { NCT00861705 }\end{array}$ & 454 & $\mathrm{~T} \pm \mathrm{Cp} \pm \mathrm{bev} \rightarrow \mathrm{ddAC}$ & $\begin{array}{l}\text { No Cp: } 41 \% \text { with Cp: } 54 \% \\
\text { No bev: } 52 \% \text { Bev: } 44 \% \\
\text { Cp and bev: } 60 \%\end{array}$ \\
\hline $\begin{array}{l}\text { Phase } 2^{36} \\
\text { NCT00930930 }\end{array}$ & 145 & Cis $+\mathrm{T} \pm$ everolimus & $\begin{array}{l}\text { Everolimus: } 36 \% \\
\text { Placebo: } 49 \%\end{array}$ \\
\hline $\begin{array}{l}\text { Phase } 2^{37} \\
\text { NCT00600249 }\end{array}$ & 35 & Cetuximab and D & pCR: $24 \%$ \\
\hline $\begin{array}{l}\text { GeparQuinto GBG } 44^{38} \\
\text { Phase } 3 \\
\text { NCT00567554 }\end{array}$ & 663 & $\mathrm{EC} \rightarrow \mathrm{D} \pm \mathrm{bev}$ & $\begin{array}{l}\text { With bev: } 39.3 \% \text { No bev: } \\
27.9 \%\end{array}$ \\
\hline $\begin{array}{l}\text { Phase } 2^{39} \\
\text { NCT00933517 }\end{array}$ & 47 & Panitumumab and FEC-D & $46.8 \%$ \\
\hline $\begin{array}{l}\text { GeparSixto GBG } 66^{40} \\
\text { Phase } 3 \\
\text { NCT01426880 }\end{array}$ & $\begin{array}{l}315 \text { (TNBC } \\
\text { cohort) }\end{array}$ & $\begin{array}{l}\text { T and Liposomal doxorubicin and } \\
\text { Bev } \pm \mathrm{Cp}\end{array}$ & $\begin{array}{l}53.2 \% \text { with } \mathrm{Cp} \\
36.9 \% \text { no } \mathrm{Cp}\end{array}$ \\
\hline
\end{tabular}

AC, doxorubicin and cyclophosphamide; Bev, bevacizumab; Cis, cisplatin; Cp, carboplatin; D, docetaxel; ddAC, dose dense doxorubicin and cyclophosphamide; EC, epirubicin and cyclophosphamide; EP, epirubicin and paclitaxel; FEC, 5-fluorouracil and epirubicin and cyclophosphamide; gem, gemcitabine; Nab-pac, nab-paclitaxel; pac, paclitaxel; PARP, poly (ADP-ribose) polymerase; T, paclitaxel; Tala, talazoparib; TNBC, triple-negative breast cancer. ${ }^{a}$ Reported as residual cancer burden (RCB) and results represent RCB 0 , equivalent to pathological complete response ( $\mathrm{pCR}$ ). 
Alkylating agents like carboplatin and cisplatin have provided additional improvements in rates of $\mathrm{pCR}$. Given that a proportion of TNBC tumours have a functional alteration in breast cancer gene 1 (BRCA1), analysis of the role of inter-strand cross-linking agents is especially prudent. The coupling of platinum-induced DNA damage and deficiencies in BRCA-associated DNA repair ${ }^{13}$ has been exploited in phase 2 trials of platinum monotherapy and yielded promising pCR rates of 23 to $90 \%{ }^{20,24,32}$, and rates of pCR were higher amongst BRCA mutation carriers $^{24,32}$. Although the randomised phase 2 GEICAM 2006-03 ${ }^{31}$ did not lead to a significant improvement in pCR, GeparSixto ${ }^{40}$ and CALGB $40603^{35}$ reported higher rates of $\mathrm{pCR}$ with the addition of carboplatin. It is important to note that the addition of carboplatin in these trials led to a significant increase in toxicity and that, for CALGB 40603, the improved pCR rate translated into a modest $5 \%$ improvement in 3-year event-free survival, which was not statistically significant ${ }^{35}$.

In further attempts to manipulate homologous recombination deficiencies inherent to $B R C A 1$ and $B R C A 2$ germline mutant tumours, poly (ADP-ribose) polymerase (PARP) inhibitors have been added to the neoadjuvant cocktail. PARP inhibitors act by inducing synthetic lethality in BRCA-deficient cells whilst sparing cells with preserved BRCA function. The phase 3 BrighTNess clinical trial saw a pCR improvement that was attributable to carboplatin rather than the PARP inhibitor under investigation, veliparib ${ }^{25}$. PrECOG 0105, a single-arm phase 2 clinical trial of gemcitabine, carboplatin and iniparib, yielded a promising pCR of $36 \%$, and response rates were higher in those tumours with elevated mean homologous recombination deficiency-loss of heterozygosity (HRD-LOH) scores, a DNAbased measure of genomic instability ${ }^{34,41}$. Although iniparib is no longer considered a true PARP inhibitor ${ }^{42-44}$, these results are compelling. It is possible that the different PARP agents will have differing efficacy because of PARP trapping ${ }^{45}$. Certainly, promising $\mathrm{pCR}$ rates were seen in patients with germline BRCA-mutated early-stage breast cancers with just talozparib alone ${ }^{26}$.

Novel agents like the monoclonal antibodies bevacizumab, panitumumab and cetuximab have been assessed with mixed results (Table 2). The randomised phase 3 GeparQuinto reported that an improvement was seen in rates of pCR with the addition of bevacizumab, but the survival analysis did not show a significant difference ${ }^{38}$.

\section{Managing residual disease following neoadjuvant chemotherapy}

Although attaining pCR is the goal of neoadjuvant therapy, optimal management of those who do not meet this end point is critical as these patients have a relapse risk that is six to nine times higher than that of patients achieving $\mathrm{pCR}^{6,7}$.

The CREATE-X clinical trial showed that six to eight cycles of adjuvant capecitabine $\left(1250 \mathrm{mg} / \mathrm{m}^{2}\right.$ from days 1 to 14 , every 21 days) improved DFS and OS in the TNBC cohort. DFS rates were $69.8 \%$ in the capecitabine arm and $56.1 \%$ in the control arm (hazard ratio [HR] 0.58 for recurrence, second cancer, or death; 95\% confidence interval [CI] 0.39-0.87), and OS rates were $78.8 \%$ and $70.3 \%$ (HR 0.52 for death, 95\% CI $0.3-0.9)^{46}$. The importance of targeting adjuvant capecitabine to those with residual disease was recently highlighted by the results of the phase 3 GEICAM/CIBOMA trial. This randomised phase 3 trial of 876 patients who had early-stage TNBC and who had completed standard adjuvant or neoadjuvant polychemotherapy was designed to analyse the impact of adjuvant capecitabine (1000 $\mathrm{mg} / \mathrm{m}^{2}$ from days 1 to 14 , every 21 days) for all patients with TNBC regardless of their pCR status. There was no significant difference in 5-year DFS and OS between the treatment groups, highlighting the need to choose a treatment-resistant group ${ }^{47}$. The results of the CREATE-X trial now compel most clinicians to treat early-stage TNBC with neoadjuvant chemotherapy in order to understand who should have capecitabine. Whilst capecitabine should be considered, ongoing trials are evaluating new agents for TNBC with residual disease after neoadjuvant chemotherapy.

\section{Does immunotherapy (CTLA4 and PD-(L)1 inhibitors) improve pathological complete response?}

The programmed cell death 1 (PD-1) inhibitors nivolumab and pembrolizumab and the programmed cell death ligand 1 (PD-L1) inhibitor atezolizumab are monoclonal antibodies designed to release inhibition of the PD-1/PD-L1-mediated immune response, whereas ipilimumab releases inhibition of the cytotoxic T-lymphocyte-associated protein 4 (CTLA4)-mediated immune response. TNBC tumour cells use the PD-1/PD-L1 and CTLA4 immune pathways to avoid immune surveillance and proliferate but these monoclonal antibodies facilitate an effective immune-mediated and anti-tumour response ${ }^{48}$.

Pembrolizumab combined with anthracycline and taxane chemotherapy has pushed the pCR boundary even further. Impressive pCR rates of up to $90 \%$ have been reported in phase $1 \mathrm{~b}$ and 2 clinical trials (Table 3 ).

Patient selection for the optimal use of these agents is important and will likely be critical to their success in terms of DFS and OS outcomes, as seen in the CREATE-X and GEICAM-CIBOMA trials. The BCT 1702-CHARIOT clinical trial (ANZCTR N12617000651381) was designed to help guide clinicians in the management of patients with TNBC that is not responding to standard neoadjuvant therapy. The phase 2 clinical trial combines paclitaxel with ipilimumab and nivolumab in eligible patients with a residual TNBC of at least $15 \mathrm{~mm}$ and less than $50 \%$ reduction in longest diameter of the tumour after completion of four standard cycles of anthracycline chemotherapy. The trial is designed to select out the most at-risk TNBC population to see whether they can derive benefit from the novel combination of therapies as these patients have been reported to have pCR rates of less than $10 \%$ and hence the highest risk of dying from their disease ${ }^{49,50}$. Furthermore, selection and duration of these myriad adjuvant therapies will be important to delineate as the outcomes of ongoing clinical trials (Table 4) are eagerly awaited.

\section{Systemic therapy for metastatic disease}

Patients with metastatic TNBC experience poorer outcomes when compared with patients with other breast cancer subtypes $^{51}$. First-line systemic treatment typically includes a 
Table 3. Neoadjuvant clinical trials in triple-negative breast cancer using combinations of chemotherapy with or without immunotherapy.

\begin{tabular}{|c|c|c|c|}
\hline Study & $\begin{array}{l}\text { Number of } \\
\text { patients }\end{array}$ & Trial arms & pCR rate \\
\hline $\begin{array}{l}\text { I-SPY } 2^{52} \\
\text { Phase } 2\end{array}$ & 69 & $\begin{array}{l}\mathrm{T} \rightarrow \mathrm{AC} \\
\mathrm{T} \text { and pembro } \rightarrow \mathrm{AC}\end{array}$ & $\begin{array}{l}\text { Control: } 22.3 \% \\
\text { Pembro: } 62.4 \%\end{array}$ \\
\hline $\begin{array}{l}\text { KEYNOTE-17353,54 } \\
\text { Phase } 1 \mathrm{~b}\end{array}$ & 20 & 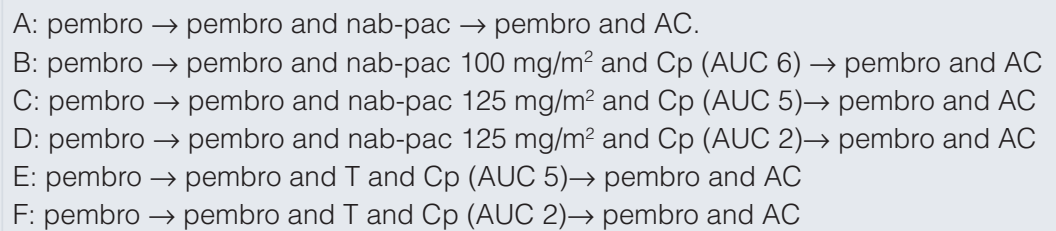 & $\begin{array}{l}\text { A: } 60 \% \\
\text { B: } 90 \% \\
\text { Overall pCR rate } \\
\text { (A-E): } 60 \%\end{array}$ \\
\hline
\end{tabular}

AC, doxorubicin and cyclophosphamide; AUC, area under curve; Cp, carboplatin; Nab-pac, nab-paclitaxel; pCR, pathological complete response; Pembro, pembrolizumab; T, paclitaxel.

Table 4. Ongoing, unreported phase 3 clinical trials of (neo)adjuvant chemotherapy with or without immunotherapy.

\begin{tabular}{|c|c|c|}
\hline Study & Agents/Intervention & Outcome of interest \\
\hline \multicolumn{3}{|c|}{ Neoadjuvant studies } \\
\hline $\begin{array}{l}\text { Impassion031 } \\
\text { NCT03197935 }\end{array}$ & $\begin{array}{l}\text { Atezolizumab } \\
\text { Nab-paclitaxel } \\
\text { Anthracyclines }\end{array}$ & $\begin{array}{l}\text { pCR } \\
\text { EFS } \\
\text { OS }\end{array}$ \\
\hline $\begin{array}{l}\text { NeoTRIPaPDL1 } \\
\text { NCT02620280 }\end{array}$ & $\begin{array}{l}\text { Atezolizumab } \\
\text { Carboplatin } \\
\text { Abraxane } \\
\text { AC, EC or FEC }\end{array}$ & $\begin{array}{l}\text { EFS } \\
\text { pCR }\end{array}$ \\
\hline $\begin{array}{l}\text { Keynote522 } \\
\text { NCT03036488 }\end{array}$ & $\begin{array}{l}\text { Pembrolizumab } \\
\text { Paclitaxel, carboplatin } \\
\text { Anthracycline }\end{array}$ & $\begin{array}{l}\text { pCR } \\
\text { EFS } \\
\text { OS }\end{array}$ \\
\hline \multicolumn{3}{|c|}{ Adjuvant studies } \\
\hline $\begin{array}{l}\text { SWOG } 1418 \\
\text { NCT02954874 }\end{array}$ & Pembrolizumab & $\begin{array}{l}\text { iDFS } \\
\text { OS } \\
\text { dRFS }\end{array}$ \\
\hline $\begin{array}{l}\text { IMpassion030 } \\
\text { NCT03498716 }\end{array}$ & $\begin{array}{l}\text { Atezolizumab } \\
\text { Paclitaxel } \\
\text { ddAC or ddEC }\end{array}$ & $\begin{array}{l}\text { iDFS } \\
\text { OS } \\
\text { DFS } \\
\text { RFI }\end{array}$ \\
\hline $\begin{array}{l}\text { A-Brave } \\
\text { NCT02926196 }\end{array}$ & Avelumab & $\begin{array}{l}\text { DFS } \\
\text { OS }\end{array}$ \\
\hline \multicolumn{3}{|c|}{$\begin{array}{l}\text { AC, doxorubicin and cyclophosphamide; ddAC, dose dense } \\
\text { doxorubicin and cyclophosphamide; ddEC, dose dense epirubicin and } \\
\text { cyclophosphamide; DFS, disease-free survival; dRFS, disease recurrence- } \\
\text { free survival; EC, epirubicin and cyclophosphamide; EFS, event-free } \\
\text { survival; FEC, 5-fluorouracil and epirubicin and cyclophosphamide; iDFS, } \\
\text { invasive disease-free survival; OS, overall survival; pCR, pathological } \\
\text { complete response; RFI, recurrence-free interval. }\end{array}$} \\
\hline
\end{tabular}

taxane or anthracycline combination ${ }^{55}$, and median OS tends to be 18 months or less ${ }^{56-58}$. Novel treatment approaches are critical to improve these dire survival outcomes.

\section{Role of poly (ADP-ribose) polymerase inhibitors and} chemotherapy for BRCA1 and BRCA2 mutation carriers The OlympiAD clinical trial randomly assigned patients with advanced HER2-negative breast cancer and a germline $B R C A$ mutation to a PARP inhibitor, olaparib (300 mg twice daily), or standard physician's choice chemotherapy ${ }^{59}$. The significant progression-free survival (PFS) benefit favoured olaparib with a median PFS of 7.2 months (versus 4.2 months) ${ }^{59}$. Subgroup analysis of PFS for randomised stratification factors revealed an outstanding HR for progression of $0.39(95 \%$ CI $0.27-0.57$ ) amongst the TNBC subset, which made up nearly $50 \%$ of the treatment cohorts in both arms ${ }^{59}$.

The EMBRACA clinical trial compared the PARP inhibitor talazoparib (1 mg daily) with protocol-specified standard therapy (capecitabine, eribulin, gemcitabine or vinorelbine) and found a favourable median PFS of 8.6 versus 5.6 months in the standard therapy group (HR for progression or death $0.54,95 \%$ CI 0.41-0.71) with a trend towards an OS benefit, but the data are immature $^{60}$. Although rates of adverse events were similar in the two treatment arms, patients randomly assigned to talazoparib reported superior quality-of-life outcomes (as recorded by the EORTC QLQ-C30) with a significant delay in the onset of a clinically meaningful deterioration in global health status ${ }^{60}$.

The results of the randomised phase 3 trials BRAVO (ClinicalTrials.gov Identifier: NCT01905592) using niraparib $300 \mathrm{mg}$ daily $^{61}$ versus chemotherapy and BROCADE (ClinicalTrials.gov Identifier: NCT02163694) using veliparib or placebo combined with chemotherapy in a similar cohort (germline $B R C A$ mutation-positive) are still pending.

The addition of iniparib to gemcitabine and carboplatin has shown promising results for all patients with metastatic TNBC regardless of their BRCA mutation status. A randomised phase 2 clinical trial showed that the addition of iniparib prolonged the median PFS from 3.6 to 5.9 months (HR for progression, $0.59 ; P=0.01)$ and the median OS from 7.7 to 12.3 months (HR for death, $0.57 ; P=0.01)^{62}$. The phase 3 clinical trial did not meet the pre-specified co-primary end points, PFS and OS, but did report an efficacy signal for patients randomly assigned 
to second- or third-line PARP inhibitor therapy ${ }^{62}$. This is likely because iniparib is no longer considered a true PARP inhibitor for the purposes of clinical research. Although iniparib inhibited PARP-1 function in vitro and was tested in clinical trials for this reason, subsequent studies have shown that the cell killing mechanism of iniparib does not reflect PARP inhibition ${ }^{42-44}$.

Notably, the Triple-Negative Breast Cancer Trial (TNT) has provided important insights into the role of platinum- and taxane-based chemotherapy ${ }^{63}$. The trial enrolled 376 patients with either a known deleterious BRCA1/2 germline mutation (and any metastatic breast cancer phenotype) or metastatic TNBC. Although no significant difference was seen in the overall TNT population, a significantly better objective response rate of $68 \%$ to carboplatin versus $33 \%$ to docetaxel was found amongst the 43 patients with a germline BRCA1/2 mutation ${ }^{63}$. Furthermore, within this population, a PFS benefit favouring carboplatin (median PFS of 6.8 versus 4.4 months) was found without a corresponding OS benefit ${ }^{63}$. Once again, the benefit was not reflected in the overall TNT population, where there was no significant PFS or OS advantage to either agent ${ }^{63}$.

\section{IMpassion 130: Will immunotherapy be the winner for advanced triple-negative breast cancer too?}

Prior to October 2018, phase 1 and 2 clinical trials evaluating PD-1 protein blockade as monotherapy in advanced TNBC showed disappointing response rates of 5 to $10 \%$ in unselected cohorts $^{64-66}$. These poor response rates likely reflect that breast cancer is not a highly immunogenic solid organ malignancy ${ }^{67}$. This has been thought to underlie the modest response rates seen with checkpoint inhibitor monotherapy to date; as a result, patients with advanced breast cancer need to be selected for the presence of pre-existing activity of the host immune system ${ }^{68,69}$. The complexity of this response, when analysed in more detail, is apparent; however, tumour-infiltrating lymphocytes (TILs) simply measured by using light microscopy on hematoxylinand-eosin-stained slides particularly have provided important insights into this variable response rate $^{70}$. TILs are mononuclear immune cells that infiltrate tumour tissue and are composed mainly of $\mathrm{CD}^{+}$and $\mathrm{CD}^{+}$(cytotoxic) $\mathrm{T}$ cells ${ }^{71}$. TILs are an independent prognostic biomarker in breast cancer, and in earlystage, node-positive TNBC, high TILs correlatewith improved survival $^{72,73}$. In addition to TILs, PD-1 and PD-L1 can be expressed by tumour cells and their presence can be evaluated as part of a detailed pathological examination of the tumour by using proprietary IHC assays ${ }^{74,75}$. In metastatic TNBC, better response rates were noted with pembrolizumab monotherapy in tumours with higher quantitative levels of $\mathrm{TILs}^{76}$. Ultimately, it is highly likely that all of these immune markers read out a similar signal for selecting patients most likely to respond to PD-1 or PD-L1 inhibition or both.

The recent approval of atezolizumab in advanced TNBC was based on the IMpassion 130 study. IMpassion 130 was a phase 3 registration study that randomly assigned over 900 patients with incurable TNBC who had relapsed 12 months or more after adjuvant chemotherapy to receive either nab-paclitaxel and atezolizumab (a PD-L1 inhibitor) or nab-paclitaxel and placebo. A statistically superior PFS benefit was seen: median PFS values of 7.2 months (95\% CI 5.6-7.2 months) in the atezolizumab and taxane arm and 5.5 months (95\% CI 5.3-5.6 months) with chemotherapy alone ( $\mathrm{HR}=0.8,95 \%$ CI $0.69-0.92 ; \quad P=0.0025)$ were reported; among the PD-L1-positive tumours, median PFS values of 7.5 months (95\% CI 6.7-9.2 months) and 5 months (95\% CI 3.8-5.6 months) were reported $(\mathrm{HR}=0.62,95 \%$ CI $0.49-0.78 ; P<0.0001)$; hence, the primary end point of the study was met $^{77}$. Interim OS analysis (60\% of events) already showed a trend towards the atezolizumab and taxane combination with median OS values of 21.3 and 17.6 months (stratified HR $0.84,95 \%$ CI $0.69-1.02)^{77}$. Furthermore, $40 \%$ of the population did not receive any prior chemotherapy. It is likely that this group of patients with metastatic TNBC does much better both in general and with immunotherapy. Still, the first steps have been taken in the field, and we have much work to do to positively impact survival in this population.

\section{What can we expect next?}

Recently, the treatment of both early and advanced TNBC has seen significant improvements in response rates and survival outcomes. The time has now come to stratify and personalise patient management according to response for early-stage disease and to the presence or absence of an immune infiltrate for advanced disease.

Patients with early-stage disease who do not achieve pCR after neoadjuvant chemotherapy should be offered six to eight cycles of adjuvant capecitabine monotherapy, in accordance with the CREATE-X trial. For patients with advanced disease who are $\mathrm{PD}-\mathrm{L}^{+}, \mathrm{CD}^{+}$, or $\mathrm{TIL}^{+}$, optimal treatment would include up-front atezolizumab and nab-paclitaxel. Exposure to a PD-1 or PD-L1 agent (or both) is likely still important for survival in patients who do not receive the combination in the first-line setting. Whether those who have a positive immune infiltrate and a disease-free interval of less than 12 months benefit from this regimen is unknown. Those without a positive immune infiltrate should be referred for a clinical trial that uses combinations of novel agents, chemotherapy and immunotherapy. The TNBC treatment landscape is an ever-evolving space, which epitomises the crucial relationship between laboratory and clinical research. The complex interplay has enabled practise-changing advances in treatment outcomes not seen in TNBC for decades.

\section{Abbreviations}

BRCA, breast cancer gene; DFS, disease-free survival; OS, overall survival; PARP, poly (ADP-ribose) polymerase; pCR, pathological complete response; PD-1, programmed cell death 1; PD-L1, programmed cell death ligand 1; PFS, progression-free survival; TIL, tumour-infiltrating lymphocyte; TNBC, triplenegative breast cancer

\section{Grant information}

The author(s) declared that no grants were involved in supporting this work.

\section{Acknowledgements}

SL and $\mathrm{AB}$ are supported by the National Breast Cancer Foundation of Australia and the Breast Cancer Research Foundation (New York, NY, USA). 
1. F Pareja F, Reis-Filho JS: Triple-negative breast cancers - a panoply of cancer types. Nat Rev Clin Oncol. 2018; 15(6): 347-8. PubMed Abstract | Publisher Full Text | F1000 Recommendation

2. $\mathrm{F}$ Hammond ME, Hayes DF, Dowsett M, et al.: American Society of Clinical Oncology/College Of American Pathologists guideline recommendations for immunohistochemical testing of estrogen and progesterone receptors in breast cancer. J Clin Oncol. 2010; 28(16): 2784-95. PubMed Abstract | Publisher Full Text | Free Full Text | F1000 Recommendation

3. F Wolff AC, Hammond MEH, Allison $\mathrm{KH}$, et al:: Human Epidermal Growth Factor Receptor 2 Testing in Breast Cancer: American Society of Clinical Oncology/College of American Pathologists Clinical Practice Guideline Focused Update. J Clin Oncol. 2018; 36(20): 2105-22.

PubMed Abstract | Publisher Full Text | F1000 Recommendation

4. Foulkes WD, Smith IE, Reis-Filho JS: Triple-negative breast cancer. N Eng/ J Med. 2010; 363(20): 1938-48. PubMed Abstract | Publisher Full Text

5. Haffty BG, Yang Q, Reiss M, et al.: Locoregional relapse and distant metastasis in conservatively managed triple negative early-stage breast cancer. $J$ Clin Oncol. 2006; 24(36): 5652-7.

PubMed Abstract | Publisher Full Text

6. Liedtke C, Mazouni C, Hess KR, et al:: Response to neoadjuvant therapy and long-term survival in patients with triple-negative breast cancer. $J$ Clin Oncol. 2008; 26(8): 1275-81.

PubMed Abstract | Publisher Full Text

7. von Minckwitz G, Untch M, Blohmer JU, et al.: Definition and impact of pathologic complete response on prognosis after neoadjuvant chemotherapy in various intrinsic breast cancer subtypes. J Clin Oncol. 2012; 30(15): 1796-804. PubMed Abstract | Publisher Full Text

8. Cortazar P, Zhang L, Untch M, et al:: Pathological complete response and longterm clinical benefit in breast cancer: the CTNeoBC pooled analysis. Lancet. 2014: 384(9938): 164-72. PubMed Abstract | Publisher Full Text

9. Spring LM, Fell G, Arfe A, et al:: Abstract GS2-03: Pathological complete response after neoadjuvant chemotherapy and impact on breast cancer recurrence and mortality, stratified by breast cancer subtypes and adjuvant chemotherapy usage: Individual patient-level meta-analyses of over 27,000 patients. Cancer Res. 2019; 79(4 Supplement): GS2-03. Publisher Full Text

10. Le Tourneau C, Dettwiler S, Laurence V, et al.: $\mathbf{4 7 \%}$ pathologic complete response rate to anthracyclines based associated with high cyclophosphamide doses neoadjuvant chemotherapy in basal-like and triple negative breast cancer patients. Breast Cancer Res Treat. 2007; 106(1): abstract 4010 .

11. Bidard FC, Matthieu MC, Chollet $P$, et al.: p53 status and efficacy of primary anthracyclines/alkylating agent-based regimen according to breast cancer molecular classes. Ann Oncol. 2008; 19(7): 1261-5. Publisher Full Text

12. Fernandez-Morales LA, Dalmau E, Martinez S, et al: Analysis of the pathological response to primary chemotherapy in patients with locally advanced breast cancer (LABC) grouped according to ER, PR and HER2 status. J Clin Oncol. 2006; 24(18_suppl): 626-6. Reference Source

13. Carey LA, Dees EC, Sawyer L, et al: The Triple Negative Paradox: Primary Tumor Chemosensitivity of Breast Cancer Subtypes. Clin Cancer Res. 2007; 13(8): 2329-34.

PubMed Abstract | Publisher Full Text

14. Keam B, Im SA, Kim HJ, et al: Prognostic impact of clinicopathologic parameters in stage II/III breast cancer treated with neoadjuvant docetaxel and doxorubicin chemotherapy: paradoxical features of the triple negative breast cancer. BMC Cancer. 2007; 7: 203 PubMed Abstract | Publisher Full Text | Free Full Text

15. Esserman LJ, Perou C, Cheang M, et al:: Breast cancer molecular profiles and tumor response of neoadjuvant doxorubicin and paclitaxel: The I-SPY TRIAL (CALGB 150007/150012, ACRIN 6657). JCO. 2009; 27: LBA515-LBA515. Publisher Full Text

16. Wang $\mathrm{S}$, Yang $\mathrm{H}$, Tong $\mathrm{F}$, et al:: Response to neoadjuvant therapy and disease free survival in patients with triple-negative breast cancer. Gan To Kagaku Ryoho. 2009; 36(2): 255-8. PubMed Abstract

17. Straver ME, Glas AM, Hannemann J, et al.: The 70-gene signature as a response predictor for neoadjuvant chemotherapy in breast cancer. Breast Cancer Res Treat. 2010; 119(3): 551-8. PubMed Abstract | Publisher Full Text

18. Huober J, von Minckwitz G, Denkert C, et al.: Effect of neoadjuvant anthracyclinetaxane-based chemotherapy in different biological breast cancer phenotypes: overall results from the GeparTrio study. Breast Cancer Res Treat. 2010; 124(1): $133-40$.

PubMed Abstract | Publisher Full Text
19. Rouzier R: Breast Cancer Molecular Subtypes Respond Differently to Preoperative Chemotherapy. Clin Cancer Res. 2005; 11(16): 5678-85. PubMed Abstract | Publisher Full Text

20. Garber JE, Richardson A, Harris LN, et al:: Neo-adjuvant cisplatin (CDDP) in "triple-negative" breast cancer (BC). Breast Cancer Res Treat. 2006; 100(1): abstract 3074

21. Sikov WM, Fenton MA, Strenger R, et al.: Preliminary recurrence and surviva analysis of patients (pts) receiving neoadjuvant q4week carboplatin and weekly paclitaxel $\mathbf{p}$ weekly trastuzumab in resectable and locally advanced breast cancer: update of BrUOG BR-95. Breast Cancer Res Treat. 2007; 106: abstract 506.

22. Torrisi R, Balduzzi A, Ghisini R, et al.: Tailored preoperative treatment of locally advanced triple negative (hormone receptor negative and HER2 negative) breast cancer with epirubicin, cisplatin, and infusional fluorouracil followed by weekly paclitaxel. Cancer Chemother Pharmacol. 2008; 62(4): 667-72. PubMed Abstract | Publisher Full Text

23. Leone JP, Guardiola V, Venkatraman A, et al:: Neoadjuvant platinum-based chemotherapy (CT) for triple-negative locally advanced breast cancer (LABC): Retrospective analysis of 125 patients. J Clin Oncol. 2009; 27(15_suppl): 625-5. Reference Source

24. Byrski T, Huzarski T, Dent R, et al:: Response to neoadjuvant therapy with cisplatin in BRCA1-positive breast cancer patients. Breast Cancer Res Treat. 2009; 115(2): 359-63.

PubMed Abstract | Publisher Full Text

25. F Loibl S, O'Shaughnessy J, Untch M, et al:: Addition of the PARP inhibitor veliparib plus carboplatin or carboplatin alone to standard neoadjuvant chemotherapy in triple-negative breast cancer (BrighTNess): A randomised, phase 3 trial. Lancet Oncol. 2018; 19(4): 497-509.

PubMed Abstract | Publisher Full Text | F1000 Recommendation

26. F Litton JK, Scoggins M, Hess KR, et al.: Neoadjuvant talazoparib (TALA) for operable breast cancer patients with a BRCA mutation (BRCA+). JCO. 2018; 36(15 suppl): 508

Publisher Full Text | F1000 Recommendation

27. Untch M, Jackisch C, Schneeweiss A, et al:: Nab-paclitaxel versus solvent-based paclitaxel in neoadjuvant chemotherapy for early breast cancer (GeparSeptoGBG 69): A randomised, phase 3 trial. Lancet Oncol. 2016; 17: 345-56. PubMed Abstract | Publisher Full Text

28. F Gianni L, Mansutti M, Anton A, et al:: Comparing Neoadjuvant Nabpaclitaxel vs Paclitaxel Both Followed by Anthracycline Regimens in Women With ERBB2/HER2-Negative Breast Cancer-The Evaluating Treatment With Neoadjuvant Abraxane (ETNA) Trial: A Randomized Phase 3 Clinical Trial. JAMA Oncol. 2018; 4(3): 302-8.

PubMed Abstract | Publisher Full Text | Free Full Text | F1000 Recommendation

29. Gluz O, Nitz U, Liedtke C, et al.: Comparison of Neoadjuvant NabPaclitaxel+Carboplatin vs Nab-Paclitaxel+Gemcitabine in Triple-Negative Breast Cancer: Randomized WSG-ADAPT-TN Trial Results. J Natl Cancer Inst. 2018; 110(6): 628-637.

PubMed Abstract | Publisher Full Text

30. Zhang $\mathrm{P}, \mathrm{Yin} \mathrm{Y}, \mathrm{Mo} \mathrm{H}$, et al.: Better pathologic complete response and relapsefree survival after carboplatin plus paclitaxel compared with epirubicin plus paclitaxel as neoadjuvant chemotherapy for locally advanced triple-negative breast cancer: A randomized phase 2 trial. Oncotarget. 2016; 7(37): 60647-56.

PubMed Abstract | Publisher Full Text | Free Full Text

31. Alba E, Chacon JI, Lluch A, et al:: A randomized phase II trial of platinum salts in basal-like breast cancer patients in the neoadjuvant setting. Results from the GEICAM/2006-03, multicenter study. Breast Cancer Res Treat. 2012; 136(2): 487-93.

PubMed Abstract | Publisher Full Text

32. Silver DP, Richardson AL, Eklund AC, et al.: Efficacy of neoadjuvant Cisplatin in triple-negative breast cancer. J Clin Oncol. 2010; 28(7): 1145-53. PubMed Abstract | Publisher Full Text | Free Full Text

33. F Werner TL, Ray A, Lamb JG, et al.: A Phase I Study of Neoadjuvant Chemotherapy With Nab-Paclitaxel, Doxorubicin, and Cyclophosphamide in Patients With Stage II to III Breast Cancer. Clin Breast Cancer. 2017; 17(7): 503-9.

PubMed Abstract | Publisher Full Text | F1000 Recommendation

34. Telli ML, Jensen KC, Vinayak S, et al:: Phase II Study of Gemcitabine, Carboplatin, and Iniparib As Neoadjuvant Therapy for Triple-Negative and BRCA1/2 Mutation-Associated Breast Cancer With Assessment of a TumorBased Measure of Genomic Instability: PrECOG 0105. JCO. 2015; 33(17): 1895-901.

PubMed Abstract | Publisher Full Text | Free Full Text

35. F Sikov WM, Berry DA, Perou CM, et al:: Impact of the addition of carboplatin and/or bevacizumab to neoadjuvant once-per-week paclitaxel followed by dose-dense doxorubicin and cyclophosphamide on pathologic complete response rates in stage II to III triple-negative breast cancer: CALGB 40603 
(Alliance). J Clin Oncol. 2015; 33(1): 13-21.

PubMed Abstract | Publisher Full Text | Free Full Text | F1000 Recommendation

36. F Jovanović B, Mayer IA, Mayer EL, et al:: A Randomized Phase II Neoadjuvant Study of Cisplatin, Paclitaxel With or Without Everolimus in Patients with Stage II/III Triple-Negative Breast Cancer (TNBC): Responses and Long-term Outcome Correlated with Increased Frequency of DNA Damage Response Gene Mutations, TNBC Subtype, AR Status, and Ki67. Clin Cancer Res. 2017; 23(15): 4035-45.

PubMed Abstract | Publisher Full Text | Free Full Text | F1000 Recommendation

37. Nabholtz JM, Chalabi N, Radosevic-Robin N, et al:: Multicentric neoadjuvant pilot Phase II study of cetuximab combined with docetaxel in operable triple negative breast cancer. Int J Cancer. 2016; 138(9): 2274-80.

PubMed Abstract | Publisher Full Text

38. Gerber B, Loibl S, Eidtmann $\mathrm{H}$, et al.: Neoadjuvant bevacizumab and anthracycline-taxane-based chemotherapy in 678 triple-negative primary breast cancers; results from the geparquinto study (GBG 44). Ann Oncol. 2013 24(12): 2978-84.

PubMed Abstract | Publisher Full Text

39. Nabholtz JM, Abrial C, Mouret-Reynier MA, et al:: Multicentric neoadjuvan phase II study of panitumumab combined with an anthracycline/taxane-based chemotherapy in operable triple-negative breast cancer: identification of biologically defined signatures predicting treatment impact. Ann Oncol. 2014; 25(8): 1570-7.

PubMed Abstract | Publisher Full Text

40. F von Minckwitz G, Schneeweiss A, Loibl S, et al.: Neoadjuvant carboplatin in patients with triple-negative and HER2-positive early breast cancer (GeparSixto; GBG 66): a randomised phase 2 trial. Lancet Oncol. 2014; 15(7): 747-56.

PubMed Abstract | Publisher Full Text | F1000 Recommendation

41. Telli ML, Timms KM, Reid J, et al.: Homologous Recombination Deficiency (HRD) Score Predicts Response to Platinum-Containing Neoadjuvant Chemotherapy in Patients with Triple-Negative Breast Cancer. Clin Cancer Res. 2016; 22(15): 3764-73.

PubMed Abstract | Publisher Full Text

42. Liu X, Shi Y, Maag DX, et al.: Iniparib nonselectively modifies cysteinecontaining proteins in tumor cells and is not a bona fide PARP inhibitor. Clin Cancer Res. 2012; 18(2): 510-23.

PubMed Abstract | Publisher Full Text

43. Patel AG, De Lorenzo SB, Flatten KS, et al:: Failure of iniparib to inhibit poly(ADP-Ribose) polymerase in vitro. Clin Cancer Res. 2012; 18(6): 1655-62. PubMed Abstract | Publisher Full Text | Free Full Text

44. Pierce A, McGowan PM, Cotter M, et al.: Comparative antiproliferative effects of iniparib and olaparib on a panel of triple-negative and non-triple-negative breast cancer cell lines. Cancer Biol Ther. 2013; 14(6): 537-45. PubMed Abstract | Publisher Full Text | Free Full Text

45. F Tutt A: Inhibited, trapped or adducted: the optimal selective synthetic ethal mix for BRCAness. Ann Oncol. 2018; 29(1): 18-21. PubMed Abstract | Publisher Full Text | Free Full Text | F1000 Recommendation

46. F Masuda N, Lee SJ, Ohtani S, et al: Adjuvant Capecitabine for Breast Cancer after Preoperative Chemotherapy. N Engl J Med. 2017; 376(22): 2147-59. Publisher Full Text | F1000 Recommendation

47. Martín M, Barrios $\mathrm{CH}$, Torrecillas L, et al:: Abstract GS2-04: Efficacy results from CIBOMA/2004-01_GEICAM/2003-11 study: A randomized phase III trial assessing adjuvant capecitabine after standard chemotherapy for patients with early triple negative breast cancer. Cancer Res. 2019; Feb 15; 79/4 Supplement): GS2-04

Publisher Full Text

48. Chen DS, Mellman I: Oncology Meets Immunology: The Cancer-Immunity Cycle. Immunity. 2013; 39(1): 1-10.

PubMed Abstract | Publisher Full Text

49. von Minckwitz G, Kümmel S, Vogel P, et al:: Intensified neoadjuvant chemotherapy in early-responding breast cancer: phase III randomized GeparTrio study. J Natl Cancer Inst. 2008; 100(8): 552-62. PubMed Abstract | Publisher Full Text

50. von Minckwitz G, Blohmer JU, Costa SD, et al:: Response-guided neoadjuvant chemotherapy for breast cancer. J Clin Oncol. 2013; 31(29): 3623-30. PubMed Abstract | Publisher Full Tex

51. den Brok WD, Speers $\mathrm{CH}$, Gondara L, et al:: Survival with metastatic breast cancer based on initial presentation, de novo versus relapsed. Breast Cancer Res Treat. 2017; 161(3): 549-56. PubMed Abstract | Publisher Full Text

52. F Nanda R, Liu MC, Yau C, et al:: Pembrolizumab plus standard neoadjuvant therapy for high-risk breast cancer (BC): Results from I-SPY 2. JCO. 2017; 35 506 . Publisher Full Text | F1000 Recommendation

53. F Schmid P, Park YH, Muñoz-Couselo E, et al:: Pembrolizumab (pembro) + chemotherapy (chemo) as neoadjuvant treatment for triple negative breast cancer (TNBC): Preliminary results from KEYNOTE-173. JCO. 2017; 35: 556. Publisher Full Text | F1000 Recommendation
54. Schmid P, Park YH, Muñoz-Couselo E, et al:: Abstract PD5-01: KEYNOTE-173: Phase 1b multicohort study of pembrolizumab (Pembro) in combination with chemotherapy as neoadjuvant treatment for triple-negative breast cancer (TNBC). Cancer Res. 2019; 79(4 Supplement): PD5-01. Publisher Full Text

55. Cardoso F, Senkus E, Costa A, et al.: 4th ESO-ESMO International Consensus Guidelines for Advanced Breast Cancer (ABC 4)†. Ann Oncol. 2018; 29(8): 1634-57. PubMed Abstract | Publisher Full Text

56. F Gobbini E, Ezzalfani M, Dieras V, et al:: Time trends of overall survival among metastatic breast cancer patients in the real-life ESME cohort. Eur $J$ Cancer. 2018; 96: 17-24.

PubMed Abstract | Publisher Full Text | F1000 Recommendation

57. F Yardley DA, Coleman R, Conte $\mathrm{P}$, et al.: nab-Paclitaxel plus carboplatin or gemcitabine versus gemcitabine plus carboplatin as first-line treatment of patients with triple-negative metastatic breast cancer: results from the tnAcity trial. Ann Oncol. 2018; 29(8): 1763-70.

PubMed Abstract | Publisher Full Text | Free Full Text | F1000 Recommendation

58. Miles DW, Diéras V, Cortés J, et al:: First-line bevacizumab in combination with chemotherapy for HER2-negative metastatic breast cancer: pooled and subgroup analyses of data from 2447 patients. Ann Oncol. 2013; 24(11): 2773-80. PubMed Abstract | Publisher Full Text

59. F Robson M, Im SA, Senkus E, et al:: Olaparib for Metastatic Breast Cancer in Patients with a Germline BRCA Mutation. N Engl J Med. 2017; 377(6): 523-33. PubMed Abstract | Publisher Full Text | F1000 Recommendation

60. F Litton JK, Rugo HS, Ettl J, et al.: Talazoparib in Patients with Advanced Breast Cancer and a Germline BRCA Mutation. N Engl J Med. 2018; 379(8): $753-63$

PubMed Abstract | Publisher Full Text | F1000 Recommendation

61. Sandhu SK, Schelman WR, Wilding G, et al.: The poly(ADP-ribose) polymerase inhibitor niraparib (MK4827) in BRCA mutation carriers and patients with sporadic cancer: a phase 1 dose-escalation trial. Lancet Oncol. 2013; 14(9): 882-92. PubMed Abstract | Publisher Full Text

62. F O'Shaughnessy J, Osborne C, Pippen JE, et al:: Iniparib plus chemotherapy in metastatic triple-negative breast cancer. N Engl J Med. 2011; 364(3): 205-14. PubMed Abstract | Publisher Full Text | F1000 Recommendation

63. F Tutt A, Tovey H, Cheang MCU, et al:: Carboplatin in BRCA1/2-mutated and triple-negative breast cancer BRCAness subgroups: the TNT Trial. Nat Med. 2018; 24(5): 628-37.

PubMed Abstract | Publisher Full Text | Free Full Text | F1000 Recommendation

64. F Dirix LY, Takacs I, Jerusalem G, et al:: Avelumab, an anti-PD-L1 antibody, in patients with locally advanced or metastatic breast cancer: a phase $1 \mathrm{~b}$ JAVELIN Solid Tumor study. Breast Cancer Res Treat. 2018; 167(3): 671-86. PubMed Abstract | Publisher Full Text | Free Full Text | F1000 Recommendation

65. Adams S, Schmid P, Rugo HS, et al.: Phase 2 study of pembrolizumab (pembro) monotherapy for previously treated metastatic triple-negative breast cancer (mTNBC): KEYNOTE-086 cohort A. JCO. 2017; 35: 1008. Publisher Full Text

66. F Emens LA, Cruz C, Eder JP, et al:: Long-term Clinical Outcomes and Biomarker Analyses of Atezolizumab Therapy for Patients With Metastatic Triple-Negative Breast Cancer: A Phase 1 Study. JAMA Oncol. 2019; 5(1): 74-82. PubMed Abstract | Publisher Full Text | Free Full Text | F1000 Recommendation

67. Martincorena I, Campbell PJ: Somatic mutation in cancer and normal cells. Science. 2015; 349(6255): 1483-9. PubMed Abstract | Publisher Full Text

68. F Adams S, Loi S, Toppmeyer D, et al.: Phase 2 study of pembrolizumab as firstine therapy for PD-L1-positive metastatic triple-negative breast cancer (mTNBC): Preliminary data from KEYNOTE-086 cohort B. JCO. 2017; 35(15_suppl): 1088. Publisher Full Text | F1000 Recommendation

69. Schmid P, Cruz C, Braiteh FS, et al:: Abstract 2986: Atezolizumab in metastatic TNBC (mTNBC): Long-term clinical outcomes and biomarker analyses. Cancer Res. 2017; 77(13 Supplement): 2986. Publisher Full Text

70. Salgado R, Denkert C, Demaria S, et al:: The evaluation of tumor-infiltrating lymphocytes (TILs) in breast cancer: recommendations by an Internationa TILs Working Group 2014. Ann Oncol. 2015; 26(2): 259-71.

PubMed Abstract | Publisher Full Text | Free Full Text

71. Ruffell B, Au A, Rugo HS, et al.: Leukocyte composition of human breast cancer. Proc Natl Acad Sci U S A. 2012; 109(8): 2796-801. PubMed Abstract | Publisher Full Text | Free Full Text

72. F Loi S, Sirtaine N, Piette F, et al.: Prognostic and predictive value of tumorinfiltrating lymphocytes in a phase III randomized adjuvant breast cancer trial in node-positive breast cancer comparing the addition of docetaxel to doxorubicin with doxorubicin-based chemotherapy: BIG 02-98. JCO. 2013; 31(7): 860-7.

PubMed Abstract | Publisher Full Text | F1000 Recommendation

73. Loi S, Michiels S, Salgado R, et al.: Tumor infiltrating lymphocytes are prognostic in triple negative breast cancer and predictive for trastuzumab benefit in early breast cancer: results from the FinHER trial. Ann Oncol. 2014; 
25(8): 1544-50.

PubMed Abstract | Publisher Full Text

74. Gatalica Z, Snyder C, Maney T, et al:: Programmed cell death 1 (PD-1) and its ligand (PD-L1) in common cancers and their correlation with molecular cancer type. Cancer Epidemiol Biomarkers Prev. 2014; 23(12): 2965-70.

PubMed Abstract | Publisher Full Text

75. Patel SP, Kurzrock R: PD-L1 Expression as a Predictive Biomarker in Cancer Immunotherapy. Mol Cancer Ther. 2015; 14(4): 847-56.

PubMed Abstract | Publisher Full Text
76. Loi $\mathrm{S}$, Adams $\mathrm{S}$, Schmid $\mathrm{P}$, et al.: LBA13Relationship between tumor infiltrating lymphocyte (TIL) levels and response to pembrolizumab (pembro) in metastatic triple-negative breast cancer (mTNBC): Results from KEYNOTE086. Ann Oncol. 2017; 28.

Publisher Full Text

77. F Schmid P, Adams S, Rugo HS, et al:: Atezolizumab and Nab-Paclitaxel in Advanced Triple-Negative Breast Cancer. N Engl J Med. 2018; 379: 2108-21.

Publisher Full Text | F1000 Recommendation 


\section{Open Peer Review}

\section{Current Peer Review Status:}

\section{Editorial Note on the Review Process}

Faculty Reviews are review articles written by the prestigious Members of Faculty Opinions. The articles are commissioned and peer reviewed before publication to ensure that the final, published version is comprehensive and accessible. The reviewers who approved the final version are listed with their names and affiliations.

\section{The reviewers who approved this article are:}

\section{Version 1}

\section{Heather L. McArthur}

Cedars-Sinai Medical Center, Los Angeles, CA, USA

Competing Interests: Heather McArthur has previously consulted or had an advisory role for Merck, Spectrum Pharmaceuticals, Lilly, Amgen, Immunomedics, Pfizer, Genentech, Bristol-Meyers Squibb and Genomic Health. Additionally, Heather was on the expert panel for Lilly in 2017.

\section{Kazuaki Takabe}

1 Division of Breast Surgery, Department of Surgical Oncology, Roswell Park Cancer Institute, Buffalo, NY, USA

2 Department of Surgery, Jacobs School of Medicine and Biomedical Sciences, The State University of New York Buffalo, Buffalo, NY, USA

Competing Interests: No competing interests were disclosed.

The benefits of publishing with F1000Research:

- Your article is published within days, with no editorial bias

- You can publish traditional articles, null/negative results, case reports, data notes and more

- The peer review process is transparent and collaborative

- Your article is indexed in PubMed after passing peer review

- Dedicated customer support at every stage

For pre-submission enquiries, contact research@f1000.com 